\title{
An Analysis of the Cycles and Periodicities of Annual Rainfall over Awka Region, Nigeria
}

\author{
Emma E. Ezenwaji1', Philip 0. Phil-Eze'2, Ifeanyi C. Enete', Bernard 0. Osuiwu ${ }^{1}$ \\ ${ }^{1}$ Department of Geography and Meteorology, Nnamdi Azikiwe University, Awka, Nigeria \\ ${ }^{2}$ Department of Geography, University of Nigeria, Nsukka, Nigeria \\ Email: emmaezenwaji@gmail.com
}

Received 31 July 2014; revised 29 August 2014; accepted 27 September 2014

Copyright (C) 2014 by authors and Scientific Research Publishing Inc.

This work is licensed under the Creative Commons Attribution International License (CC BY).

http://creativecommons.org/licenses/by/4.0/

(c) (i) Open Access

\section{Abstract}

The aim of this study was to analyse the cycles and periodicities of annual rainfall over Awka region, Nigeria. This is necessitated by the fact that, despite the fact that wet years contribute greatly to annual flooding and gully erosion observed in the area, researches on cycles and periodicities of rainfall in the area are obviously lacking. This research is, therefore, an attempt to close this gap in knowledge. 35 years rainfall data (1975-2010) were collected from the Nigerian Meteorological Agency (NIMET) Lagos from which harmonic calculation was made using Harmonic Analytical Technique. The model produced 13 harmonics (cycles) of which those of 1, 6 and 11 with amplitudes of $181.66 \mathrm{~mm}, 149.42 \mathrm{~mm}$ and $126.63 \mathrm{~mm}$ and periodicities of $35,5.20$ and 2.84 were isolated as most important. All calculations were performed using MINITAB version 16 statistical programme running under $\mathrm{PC} /$ Windows 98. Following from the findings, it was suggested that Urban and Regional Planners, Geomophologists and Engineers could use the result to develop a flood and erosion management plan for the area.

\section{Keywords}

Component, Formatting, Style, Styling

\section{Introduction}

The rainfall of any area is a rich resource that can be harnessed for a range of purposes. For example, the onset and cessation of rainfall have been studied for various areas of Nigeria for the improvement of rain fed agriculture [1]-[5]. Furthermore, [6] employed rainfall data to explain the effect of deforestation on climate change over the Anambra River Basin. He utilized a 20-year rainfall data to calculate dates of onset, end and duration of the rainy season thus establishing a rainfall pattern that has been altered after the area was deforested to create 
5000 hectares of rice fields. Furthermore, rainfall patterns have been studied to ascertain its effect on water supply in some localities. [7] investigated the effects of droughts, rainfall and rural water supply in Northern parts of Nigeria, while [8] utilized rainfall trends of 11 meteorological stations over a period of 34 years (1971-2004) to establish the extent of flooding in Northern Nigeria. While some of these researchers employed trend analysis in their studies, others merely calculated the beginning and end of the rain using various methods, of which the most universal are the walter and ogive. However, ascertaining the rainfall trend only does not reveal a sequence or pattern that must necessarily repeat itself after an interval of time which are used to predict adverse climatic events that may be employed for production and adoption of suitably desired responses. For example cycles and periodicities are utilized in the prediction of the rainfall amounts for any particular year or time which could form the basis for the forecast of extreme climatic conditions in an area such as drought and flooding as well as associated soil and meteorological problems. Forecasts are usually helpful for issuing warnings concerning the incoming extreme events. The failures of researchers either to regularly engage in this type of study or for government to use research findings of such studies for planning are reasons why we are often taken unawares by the often repeat of the events. It is no longer news that every year floods destroy property worth billions of Naira in most urban and rural areas of Nigeria which could have been prevented had people known the years, month or even the day that may likely experience such events based on the amount of expected rainfall. The study of the cycles and periodicities of rainfall in Awka region is one of the attempts to provide the needed information on the forecast of rainfall of the area with a view to employing the knowledge revealed in issuing warning to inhabitants about the likelihood or otherwise of such events. Adherence to such warnings will however help in no small measure to minimize the repeated adverse effects of the events in the area.

\section{Materials and Methods}

\subsection{Area of Study}

Awka Region is located in the eastern parts of Anambra State and covers the entire capital territory which comprises Awka South and some parts of Awka North, Dunukofia, Njikoka and Anaocha Local Government Areas (Figure 1).

The region is bound by Latitudes $6^{\circ} 07^{\prime}$ and $6^{\circ} 17^{\prime} \mathrm{N}$ and Longitudes $7^{\circ} 00^{\prime}$ and $7^{\circ} 10^{\prime} \mathrm{E}$ and made up of 26 communities. 2011 population was projected at 633029 while some of the communities are either wholly urbanized or seriously urbanizing. [9] referred to this region as an emergent conurbation of polynuclear type. The entire region is fast turning into a continuously built-up area that in very near future the whole region would become a vast urbanised zone. In terms of typography, the area is sharply divided into two, the upland areas of the west with the highest point being about $800 \mathrm{~m}$ and located around EnugwuUkwu and Abagana and the low lands and plains of the east and north which could be seen around Ezinato, Amansea as well as northwards in Mgbakwu, Urum, Ebenebe and other communities around them. Geologically, over $80 \%$ of the area consists of Imo shale group of lower eoceneera while a small band of Nanka sands are seen in the western parts of the region [10]. The climate is wet equatorial with average maximum temperature of $29^{\circ} \mathrm{C}$ and average minimum temperature of $23^{\circ} \mathrm{C}$. Mean annual rainfall is about $1824 \mathrm{~mm}$ with the relative humidity $\mathrm{RH}$ of $80 \%$ at dawn. The vegetation is rainforest which has largely been disturbed by urbanization and other human activities, thus leaving a derived vegetation as outliers within the region. The region is well drained by such rivers as Mamuand Obibia in the east, Obizi in the north and Idemiliriver and Agululake in the south.

\subsection{Data Collection and Analysis}

Rainfall data for the area for a period of 35 years (1975-2010) were collected from the Nigerian Meteorological Agency (NIMET) Oshodi Lagos and used for the analysis (Table 1).

In analysing the data, harmonic analytical technique was employed. Ordinarily trend analysis produce irregular or even complex curves (or fluctuations) which can be expressed mathematically as the algebraic sum of a series of simple sine and cosine curves with amplitudes and frequencies or harmonics [12]. The mathematical expression is written as:

$$
f(x) \bar{X}+\sum_{r=1}^{r=N / 2}\left[\operatorname{arCos}\left(\frac{2 \pi r x}{p}\right)+b r \operatorname{Sin}\left(\frac{2 \pi r x}{p}\right)\right]
$$




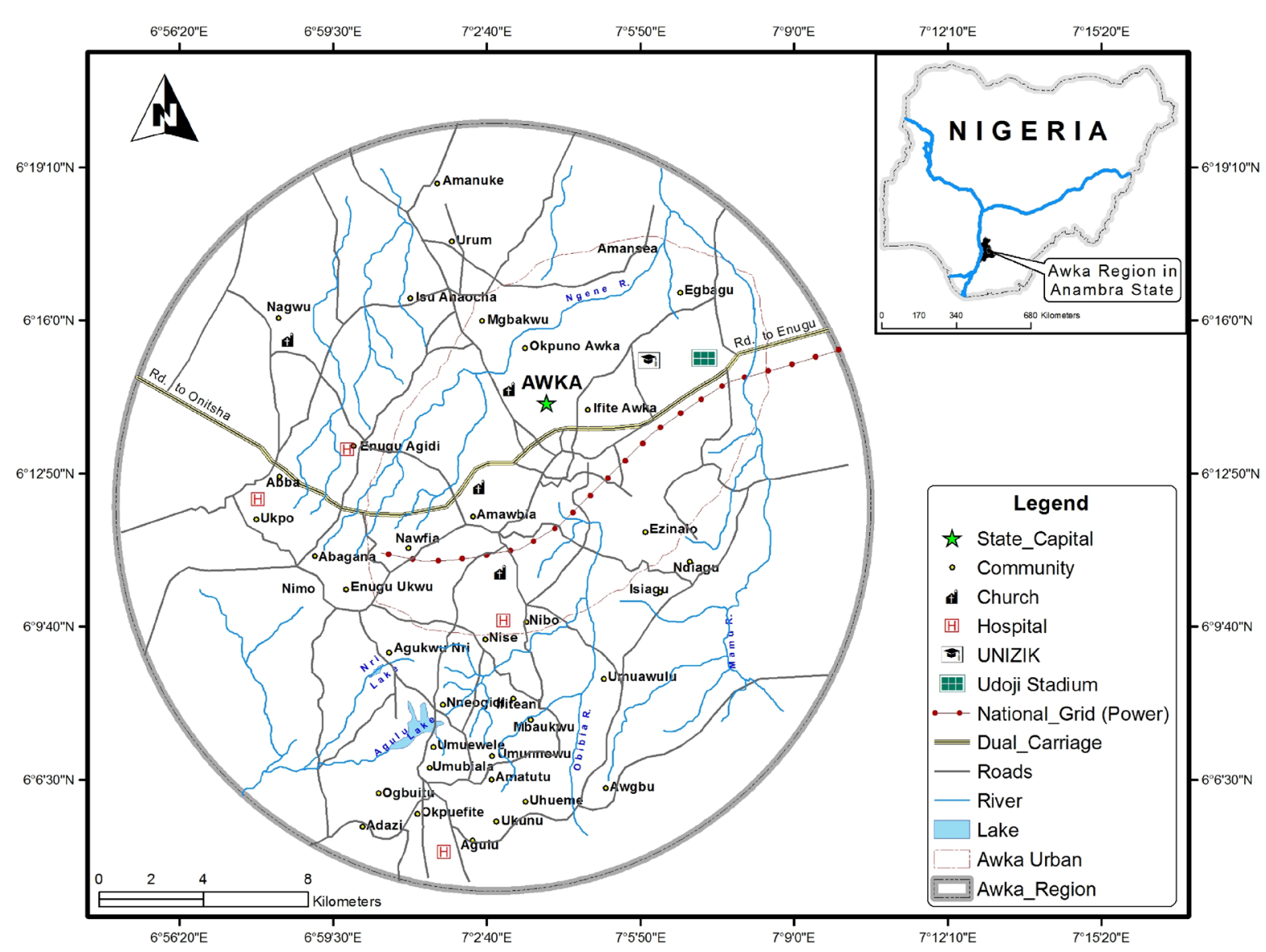

Figure 1. Map showing Awka Region, Nigeria.

Table 1. Annual rainfall of Awka Region (1975-2010).

\begin{tabular}{cccccc}
\hline Year & Rainfall & Year & Rainfall (mm) & Year & Rainfall \\
\hline 1975 & 1322 & 1988 & 2006 & 2001 & 1551 \\
1976 & 2021 & 1989 & 1790 & 2002 & 1778 \\
1977 & 1781 & 1990 & 2012 & 2003 & 1882 \\
1978 & 1790 & 1991 & 2080 & 2004 & 2084 \\
1979 & 1832 & 1992 & 1810 & 2005 & 2016 \\
1980 & 1679 & 1993 & 1605 & 2006 & 2031 \\
1981 & 1840 & 1994 & 2090 & 2007 & 1660 \\
1982 & 1719 & 1995 & 2469 & 2008 & 1849 \\
1983 & 1383 & 1996 & 1825 & 2009 & 1960 \\
1984 & 1682 & 1997 & 1907 & & \\
1985 & 1795 & 1998 & 2081 & & \\
1987 & 1507 & 2000 & 2059 & & \\
\hline
\end{tabular}

Source: [11].

where $a$ and $b$ are Fourier coefficients for the cosine and sine terms respectively $r$ is any harmonic (cycle); $x$ is the individual time units (which could be years months or days) $p$ is the fundamental period (i.e. the total num- 
ber of time units).

$N=p$

The Fourier coefficients $a \& b$ for each harmonic (cycle) are expressed as

$$
\begin{aligned}
& a_{r}=2 / N \sum\left[Y \operatorname{Cos}\left(\frac{2 \pi r x}{p}\right)\right] \\
& b_{r}=2 / N \sum_{x=1}^{N}\left[Y \operatorname{Sin}\left(\frac{2 \pi r x}{p}\right)\right]
\end{aligned}
$$

Equations (2) \& (3) could be rewritten as

$$
\begin{gathered}
a_{r}=2 / N \sum_{x=1}^{N}\left[Y \operatorname{Cos}\left(\frac{360 r x}{p}\right)\right] \\
b_{r}=2 / N \sum_{x=1}^{N}\left[Y \operatorname{Sin}\left(\frac{360 r x}{p}\right)\right]
\end{gathered}
$$

where $a_{r}$ and $b_{r}$ are coefficients for each harmonic;

$N$ is the length of the Time Series;

$Y$ is each value of time series;

$x$ are the individual time units (i.e. 1 to $N$ );

$r$ is any harmonic (from $r=1$ to $r=N / 2$ ); and

$p$ is the fundamental period $N$.

The percentage variance $(\% \mathrm{~V})$ explained by any harmonic or cycle is given by

$$
\% V=\left(\frac{a_{r}^{2}+b_{r}^{2}}{2 s y^{2}}\right) \times 100 .
$$

where sy is the Standard Deviation of $Y$ (i.e. the individual values of time series).

It could be said that the any harmonic is a function of the size of a parameter called the amplitude. This means that those harmonics which best fits the time series curve will have the largest amplitudes, while those with poor fit will have small amplitudes [12]. The Amplitude $A$ is given as

$$
A=\sqrt{a_{r}^{2}+b_{r}^{2}}
$$

The maximum number of harmonics that can be extracted from a Time Series is therefore $N / 2$ because after $N / 2$ harmonics the values "wrap" round and begin another round of duplication. Periodicities are determined by dividing the length of the time series by harmonic number $r$, i.e. each period is $N / r(8)$.

The harmonic analysis was carried out using MINITAB version 16 program running under PC/Windows 98. For the purpose of this research, only dominant cycles determined on the basis of the percentage contribution of variance explained were selected.

\section{Results and Discussions}

The statistical package which calculated the harmonics of our rainfall data for Awka region produced the result on Table 2 and the graph depicting the cycles on Figure 2.

As is usual with the practice 3 dominant cycles are usually selected. These are Harmonic's 1, 6, and 11. The representative cycles have periodicities of 35, 5.20 and 2.84 years. Their details and presented in Table 3 .

It would therefore appear that the dominant cycle of rainfall series of Awka Region and one that explains 26.4\% of the variance is that with a periodicity of 35 years. This means that this cycle repeats itself every 35 years and associated with the rainfall amounts of $181.66 \mathrm{~mm}$. When the cycle repeats itself this long, it is a clear analogy to the 35-year normal period which the climatologists use.

Also the second dominant cycle in the area is the one which explains $18.30 \%$ of the variance and this could be interpreted to mean that the cycle repeats itself 6 times every 5.20 years which is roughly once every year approximately with an amplitude of $149.62 \mathrm{~mm}$. Finally the third dominant cycle shows that it has a periodicity of 


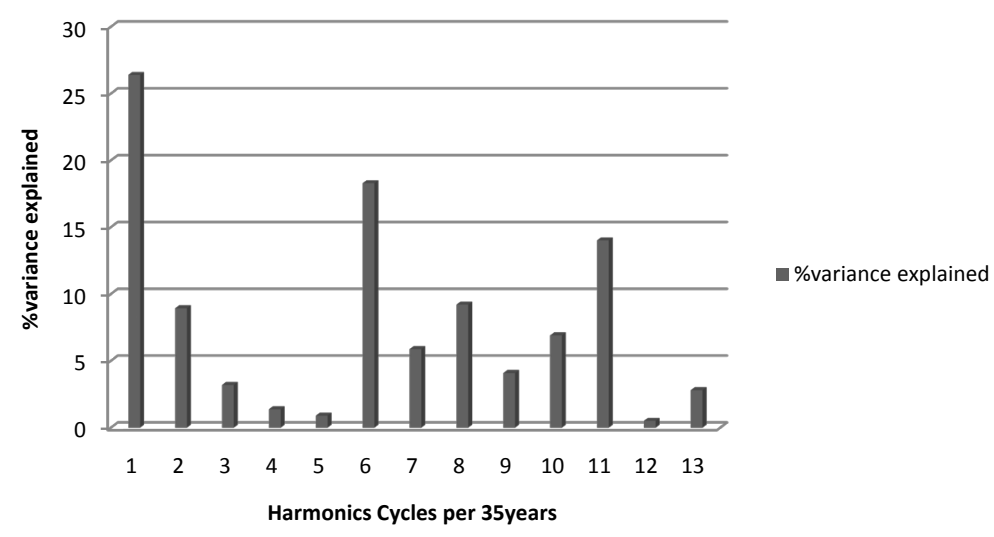

Figure 2. Bar chart of harmonic cycles per 35 years.

Table 2. Harmonic analysis of annual rainfall of Awka Region.

\begin{tabular}{cccc}
\hline Harmonics (Cycles) per 35 yrs & Cycles (years) & \% of Variance Explained & Amplitude (mm) \\
\hline 1 & 35 & $26.40^{*}$ & $181.66^{*}$ \\
2 & 16 & 8.94 & 74.32 \\
3 & 12 & 3.20 & 39.66 \\
4 & 8.41 & 1.38 & 38.10 \\
5 & 6.0 & 0.90 & $149.62^{*}$ \\
6 & 5.20 & $18.3^{*}$ & 82.40 \\
7 & 4.10 & 5.88 & 96.35 \\
8 & 3.80 & 9.21 & 60.82 \\
9 & 3.25 & 4.09 & 88.25 \\
10 & 3.10 & 6.91 & $126.63^{*}$ \\
11 & 2.84 & $14.02^{*}$ & 13.33 \\
\hline
\end{tabular}

*Important harmonics. Source: Author's calculation.

Table 3. Dominant rainfall cycles of Awka Region, Nigeria.

\begin{tabular}{cccc}
\hline Order of Importance & Harmonics Cycles per 35 years & Periodicity (year) & \% of Variance Explained \\
\hline 1st & 1 & 35 & 26.40 \\
2nd & 6 & 5.20 & 18.30 \\
3rd & 11 & 2.84 & 14.02 \\
\hline
\end{tabular}

Source: Author's calculation

11 times in 2.50 years and is translated to mean once in approximately 4 months with the total rainfall amounts (amplitude) of $126.13 \mathrm{~mm}$. What all these mean is that we shall be having $149.62 \mathrm{~mm}$ amount about once every year and $126.13 \mathrm{~mm}$ once every 4 months. However the amount of $181.66 \mathrm{~m}$ is once every 35 years. The graphical presentation of the harmonics and percentage of variance explained could be seen in Figure 2. From that figure it is easily discernible that the 1st, 6th and 11th harmonics are clearly dominant. 
Awka region has been known for extreme climatic events of flooding which ravages every part of Awka urban area and outlying regions every rainy season. Although, there are anthropogenic factorsgiven rise to flooding, if one of natural factor which is the rainfall events are well predicted, it would help in no small measure in alleviating the often terrible effects of flooding in the area. [13] tried to identify the causes of flooding in Awka town, but removed the pivotal role of rainfall, but other studies such as those of [14]-[17], located the primary cause of flooding on rainfall events, in other areas of Nigeria. The historic Sokoto flooding of 2010 and those of Kano and other parts of arid northern parts of Nigeria are all traced to the sudden upsurge of rainfall amounts in the affected areas. Also flooding has led to other problems in Awka region of Nigeria, and one of the major problems is soil erosion. The fact that the upland areas of the region is made up of highly friable sandstones which are susceptible to erosion and characterise by the infamous Agulu-Nanka gully erosion, is an indication of the deleterious effect of rainfall on the landscape. [18] [19] established the paramouncy of rainfall as a factor of soil erosion in our study area.

The use of cycles and periodicities of rainfall to check the problems of flooding and soil erosion is therefore of supreme importance. This is because the result will definitely help to identify the years that are likely to receive large amounts of rainfall which will form the basis upon which warning signals could be sent to the inhabitants of possible flooding. [20] for instance did suggest that the ability to predict the weather conditions always help warn people to relocate from either a flood or erosion prone areas during a manifest wet year.

\section{Conclusion}

We have in this study determined through harmonic analysis the cycle of rainfall in Awka region of Nigeria which can surely be used to predict the cycle and periodicities of rainfall in the area with a view to employing the result to inform the inhabitants of impending extreme climatic conditions. Against this background we strongly recommend that the identified cycles in this study be employed for the flood and erosion plans of the area. We identified these two problems because they are the ones that have mostly devastated the area. Also we recommend that similar study should be done in other small regions of the country especially the areas which are experiencing aggressive urbanization. Finally, this result could be used in all the areas with similar rainfall characteristics as Awka region.

\section{References}

[1] Adebayo, A.A. and Adebayo, E.F. (1997) Precipitation Effectiveness Indices and Upland Rice Yield in Adamawa Sate. Annals of Borno, 13/14, 266-276.

[2] Ayoade, J.O. (2003) Climate Change: Synopsis of its Nature, Causes, Effects and management. Vantage Publishers, Ibadan.

[3] Odekunle, T.O. (2004) Rainfall and the Length of the Growing Season in Nigeria. International Journal of Climatology, 24, 467-479. http://dx.doi.org/10.1002/joc.1012

[4] Umar, A.T. (2010) Climate Change: Treat to Food Security and Livelihood in Selected States of Northern Nigeeria. In: Ogidiolu, A., Musa, S.D., Ogbonna, D.O. and Ifatimehin, O.O., Eds., Contemporary Issues in Infrastructure Development and Management in Nigeria, Jas Ventures, Anyigba, 23-30.

[5] Sawa, B.A. and Adebayo, A.A. (2011) Climate Change and Yield of Grain Crops at Samaru, Zaria. Nigerian Journal of Geography and the Environment, 2, 255-265.

[6] Ayadiuno, R.U. (2011) Effects of Deforestation on Climate Change over Anambra River Basin. Nigeria Journal of Geography and Environment, 2, 266-273.

[7] Aondover, A.T. (1997) Drought, Rainfall and Rural Water Supply in Northern Nigeria. Ph.D. Thesis, McMaster University, Hamilton, Canada.

[8] Nwagbara, M.O., Ijioma, M.A. and Chima, G.N. (2010) Climate Change and Flooding in Northern Nigeria: An Examination of Rainfall Trends over the Region. In: Anyadike, R.N.C., Madu, I.A. and Ajaero, C.K., Eds., Climate Change and the Nigerian Environment, Jamoe Publishers, Enugu, 101-112.

[9] Okoye, T.O. (1981) Conflict between Urban and Rural Land Uses in an Emerging Conurbation. In: Igbozurike, U.M., Ed., Land Use and Conservation in Nigeria, University of Nigeria Press, Nsukka, 251-263.

[10] Orajiaka, S.O. (1975) Geology. In: Ofomata, G.E.K., Ed., Nigeria in Maps: Eastern States, Ethiope Publishing House, Benin City, 5-7.

[11] NIMET (2011) Rainfall Data for Parts of S.E. States Nigeria. Nigerian Meteorological Agency (NIMET), Abuja. 
[12] Anyadike, R.N.C. (2010) Statistical Methods for the Social and environmental Sciences. Spectrum Books Ltd., Ibadan.

[13] Muoghalu, L.N. and Okonkwo, A.O. (1998) Effects of Urban Flooding in Awka, Capital of Anambra State Nigeria. Environmental Review, 2, 69-77.

[14] Odemerho, F.O. (1993) Flood Control Failures in a Third World City: Benin City, Nigeria-Some Experimental Factors and Policy Issues. GeoJournal, 29, 371-376. http://dx.doi.org/10.1007/BF00807539

[15] Geoffrey, L. (2011) Rainfall Events in City Flooding: A Case Study of Kampala, Uganda. Journal of Tropical Climate, 6, 71-84.

[16] Gray, M. (2005) The Rains in Tropical Wet (Ar) Climate Region of West Africa and Implications on City Flooding. In: Odukolo, J., Ed., Climatic Characteristics of Some African Cities, Ederson Publication, Pretoria, 199-120.

[17] Sadat, B. (2009) The Rainfall of the Mediterranean Coasted Cities of Africa. Journal of Coastal Development, 2, 320331.

[18] Ofomata, G.E.K. (1981) The Land Resources of South Eastern Nigeria: A Need for Conservation. In: Igbozurike, U.M. (Ed.), Land Use and Conservation in Nigeria, University of Nigeria Press, Nsukka, 94-106.

[19] Ude, N.C. (1981) Ranking the Gullies of Imo and Anambra States According to Reclamation Need. A Decision Theory Approach. In: Igbozurike, U.M., Ed., Land Use and Conservation in Nigeria, University of Nigeria Press Nsukka, 33-44.

[20] Anyaduba, J.O. (2003) Flood Warning in Urban Communities as a Planning Tool. Journal of Flood and Wetland, 2, $32-40$. 
Scientific Research Publishing (SCIRP) is one of the largest Open Access journal publishers. It is currently publishing more than 200 open access, online, peer-reviewed journals covering a wide range of academic disciplines. SCIRP serves the worldwide academic communities and contributes to the progress and application of science with its publication.

Other selected journals from SCIRP are listed as below. Submit your manuscript to us via either submit@scirp.org or Online Submission Portal.
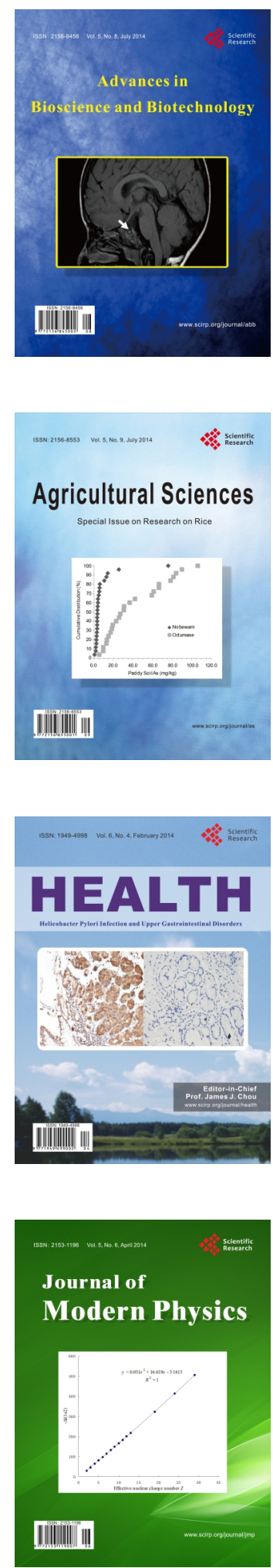
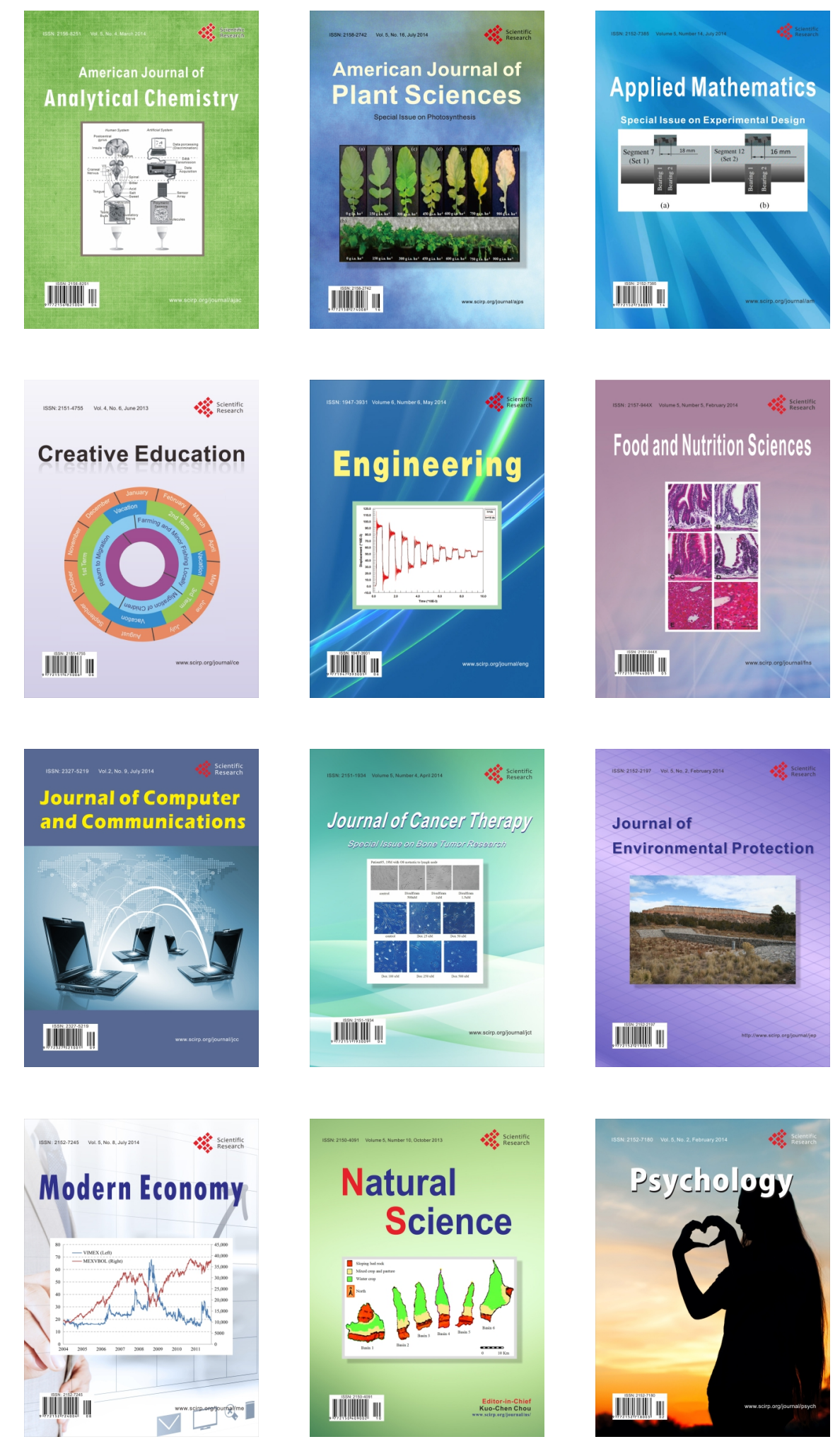